\title{
The impact of interwoven integration practices on supply chain value addition and firm performance
}

\author{
Shashi $^{1} \cdot$ Madjid Tavana $^{2,3} \cdot$ Amir Shabani $^{4} \cdot$ Rajwinder Singh $^{1}$
}

Received: 9 April 2019 / Accepted: 6 July 2019 / Published online: 19 July 2019

(c) The Author(s) 2019

\begin{abstract}
Drawing on the supply chain (SC) management literature, this article conceptualizes and empirically tests a framework that shows how both external and internal integration practices are significant and positively associated with SC value addition and firm performance. The framework also tests the impact of value addition as a reinforcing factor on firm performance. The outcome of this investigation is interesting for both SC researchers and practitioners because the current SC integration literature is conflicting. A structural equation modeling technique, using a sample of 366 large-scale manufacturing companies based in India, is considered in this paper to test the framework. The results support all five research hypotheses which indicate that paramount firm performance requires tight external and internal integration and higher level of value addition. Although the external integration is found to be rather influential than the internal integration, SC players need to have integrated internal business processes for tight external integration. This paper also explains the implication of collective planning and decision making to respond promptly to external market events and reveals the importance of value addition.
\end{abstract}

Keywords Supply chain management $\cdot$ Planning $\cdot$ Integration $\cdot$ Value addition $\cdot$ Firm performance

\section{Introduction}

In today's highly volatile business environment, companies' internal capabilities and competences are not adequate to compete in the global market. Thus, to cope with these challenges, foster mutual benefits and maintain own competitiveness, companies together with their partners are looking at ways to find novel supply chain (SC) management methods for sustainability in the global marketplace (Flynn et al. 2010; Jacobs et al. 2016; Ataseven and Nair 2017). The literature offers various definitions of SC management that imply a strong link between SC management and the concept of integration: "SC management is an integrative philosophy to control the entire distribution channel, starting from the supplier to the end customers" (Cooper et al. 1997), whereas Lambert et al. (1998) defined SC management as an 'integration of multiple firms' processes associated with flow of information, product and services for adding the value for firm's buyers and other stakeholders." Hence, SC integration is the creation of value on the one hand, and SC management performance improvement on the other hand (Shashi et al. 2017).

Nowadays, professionals engaged in managing a SC make interventions in adding value actions of SC 
upstream-facing suppliers and SC downstream-facing customers. Meanwhile, the SC integration has become a crucial factor in gaining both service and cost advantage and anticipated to play a central role in planning (TarifaFernandez and De Burgos-Jimenez 2017). Cooper et al. (1997) represent the view that manufacturing firms should fully integrate with partners to serve stakeholders in better ways than competitors. Attaining and executing SC integration, nevertheless, among SC partners are challenging. However, it may generate numerous economic or noneconomic benefits to companies (Ataseven and Nair 2017).

Value addition in SC involves managing processes and activities that make product or services more desirable to customers and foster the demands of firm's product or service at the marketplace, which in turn improve the firm's market share and profitability (Shashi et al. 2017). The SC literature advocates that value addition thought and practices build a competitive advantage by improving the chain efficiency, service rate, product quality and consumer satisfaction as well as reducing the cost, waste and lead time (Matthews 2013). Likewise, value addition builds the brand value of SC and plays a pivotal role in increasing customers and promoting a win-win strategy for the chain partners (Zhang and Wang 2018). Shashi et al. (2017) have shown effective integration with the chain members is a prerequisite to realize the benefits from SC value addition.

Due to globalization and the constant emergence of new players, companies have tremendous pressures to reduce lead times, shipping errors, costs and improve overall SC value. Thus, resource sharing, utilization of the capacities of third parties and deeper reliance on bought-in expertise may assist in reducing this pressure (Tarifa-Fernandez and De Burgos-Jimenez 2017). Lambert and Cooper (2000) report that high integration of business process in SC leads to superior network efficiencies. Additionally, its integration facilitates in knowledge creation, sharing the risk, better decision making, a seamless flow of goods/services and mutual benefits (Gunasekaran and Ngai 2004; Finger et al. 2014).

In the last decade, dozens of empirical and review articles have been published on SC integration (Kim 2009; Beheshti et al. 2014; Ataseven and Nair 2017). In spite of that, there are very few studies analyzing the simultaneous effect of integration and $\mathrm{SC}$ value addition on the firm performance. Therefore, to fill this gap, this study investigates the following research questions:

1. To what extent does the external integration associate with firm performance?

2. To what extent does the internal integration associate with firm performance?

3. To what extent does the external integration associate with value addition?
4. To what extent does the internal integration associate with value addition?

5. To what extent does SC value addition associate with firm performance?

In this study, we focus on the Indian manufacturing industry because India has emerged among as an attractive destination for investment in the manufacturing sector (IBEF 2019). Consequently, cumulative foreign direct investment has grown drastically and the government has increased the manufacturing sector's share in gross domestic product. In addition, the government has increased the liberalization and relaxed the tariffs to grow the sector. Finally, government initiatives such as "Make in India" and National Manufacturing Competitiveness Program have revitalized the Indian manufacturing industry (Shashi et al. 2019).

The remainder of this study is structured as follows: Section 2 reviews the relevant literature. Section 3 presents the conceptual framework. Thereafter, research methodology is discussed in Sect. 4, and Sect. 5 demonstrates the result. The research implications and conclusions are given in Sects. 6 and 7 , respectively.

\section{Literature review}

Adding value through SC integration has become one of the most promising ways of securing market competencies and improving performance, since business battle is no longer between companies, but among SCs (Pal 2017). A significant stream of research has pertained to a higher level of SC integration with increased SC responsiveness and superior performance. Kim and Chai (2016) identified business uncertainty as the primary cause of raising the need to explore and evaluate each type of SC integration for survival in highly competitive environments, while Zhu et al. (2017) identified SC integration as a risk management strategy. Frohlich and Westbrook's (2001) presented a framework of "arcs of integration" which conceptualizes customers and suppliers' integration and measured performance. Many researchers have recognized this study by quoting it in their own research (Pagell 2004; Flynn et al. 2010). The findings of some investigations suggest a positive and direct association between integration and performance ( $\mathrm{Pal}$ 2017; Shou et al. 2018). A recent study advocated that SC integration enables firms to improve their operational and financial performance (Ataseven and Nair 2017). Furthermore, Aharonovitz et al. (2018) argued supplier selection strongly and positively impacts logistics collaboration, which further affects logistics performance. Morita et al. (2018) called integration of product development and SC capability a driver for superior performance. However, the other researchers do not find such an association (Zhao et al. 2015). 
Scholars define the term SC integration by using varied statements. Few researchers have focused on integration with customers which involves collection of information (Kim 2009) or suppliers (Smith and Rupp 2013) to define SC integration impact on SC performance. In other investigations, researchers expand the scope of SC integration by allowing for both supplier's and customer's requirements (Swink et al. 2007; Droge et al. 2012) and define it as the sole and broader concept involving both upstream and downstream partners. The alliance with suppliers and customers is usually denoted as external integration. However, the impact of supplier and customer integration on a firm's operational performance varies across production systems (Shou et al. 2018).

Apart from this, few authors studied internal integration which refers to the integration of business functions such as product design, purchasing, manufacturing, marketing and distribution, within an organization (Zailani and Rajagopal 2005; Jacobs et al. 2016). Finger et al. (2014) document that external integration offers access to external sources of technology and knowledge, whereas internal integration offers a structure for adjusting external technology and knowledge. The results of Sawhney (2006) show that internal integration promotes knowledge exchange and causes better coordination of the capacity of the manufacturer to enhance production flexibility. However, external SC integration may be more powerful than internal integration (Vickery et al. 2003). Furthermore, Flynn et al. (2010) classify SC integration into three branches: internal, customers and suppliers. Similarly, Wang et al. (2018) pointed out that interpersonal and inter-organizational relationships influence the success of integration, and Kang et al. (2018) reported both upstream and downstream integrations are predictors of intra- and inter-firm sustainable practices.

Noori-daryan and Taleizadeh (2019) attempted to foster the profitability of the entire SC through optimizing the suppliers' order quantity and selling prices of both manufacturer and wholesaler. Pinha and Ahluwalia (2019) presented a procedure to confine both project cost and time through empowering managers to examine various scenarios. Kanyoma et al. (2018) show the firm size is a dominant factor for the integration and small-medium enterprises are considered as unattractive partners. Hafezalkotob and Zamani (2019) proposed a model to evaluate the impacts of the financial intervention of governmental on green SC.

The importance of integration strategy, in addition to integration scope, is very critical. Both lean and agile SC needs tight internal and external integration (Qi et al. 2017). Highly extended SC integration allows manufactures to reduce inventory, cost and lead time and endorse to more SC flexibility which maximizes the firm's value addition efficiency (Barrat 2004; Kampstra et al. 2006). Similarly, Liao et al. (2017) argued that collaborative SC value creation leads to cost, delivery, product, and market efficiency. The regular improvement in product quality in the $\mathrm{SC}$ is known as essential value addition trait (Sofiana et al. 2019). Hong and Jeong (2019) presented a model to decide an efficient facility location-allocation model, and Sebatjane and Adetunji (2019) designed a lot-sizing procedure under the incremental quantity discounts by discounts. Khorasani and Almasifard (2018) offered a dualobjective facility model for an environmental-friendly SC network.

Chen and Paulraj (2004) emphasize on the collaborative advantage paradigm of SC which includes environmental uncertainty, sourcing, supply structure information technology and logistics integration as influencing buyer-seller relations and consequently resulting in unique value delivery. Nevertheless, companies should not ignore the role of internal communication in the successful SC integration (Jacobs et al. 2016). Development of SC value addition strategies and its application in each SC stage depend upon several factors, namely infrastructure, finance, resources, expertise and technology (Matthews 2013).

Green et al. (2006) claim that if each department of the $\mathrm{SC}$ is working to optimize its own value, there will be discontinuities at the interfaces and unnecessary costs will result. Saeed et al. (2018) highlighted the role of decisions associated with SC and product architecture in attaining organizational competitiveness. Power (2005), on the other hand, report that the SC integration does not always positively influence the tangible or non-tangible firms' performance and the possible benefits associated with integration are ambiguous (Pagell 2004).

Based on the above argument, it could be contended that the collaborative and integrative advantage cannot be achieved by companies because of their inability to collaborate with SC members effectively and professionally. In its support, Sambasivan et al. (2011) report that nearly 70 percent of SC relationships tend to fail. The recent work of Wiengarten et al. (2016) quoted that some studies failed in explaining the role of SC integration in value addition and improving SC performance. Moreover, it seems that adequate interactions between different areas of integration are somewhat ignored. Other concerns related to the hypotheses and measurements differ among/from the literature. Few survey-based studies on integration deliberate single links and associations, while many other authors measure integrative practices and their association with performance as a company variable, valid for all links with buyers and suppliers (Johnston et al. 2004). Despite the increased attention paid to integration, the literature has not been able to explain the right relationship between SC and value addition and firm performance. Therefore, this study is an attempt to fill this research gap. 


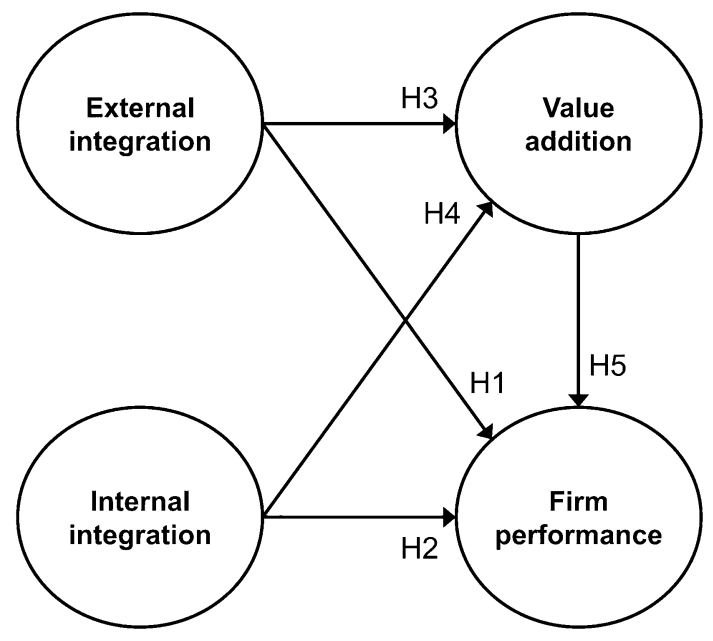

Fig. 1 Conceptual model

\section{Conceptual model and hypotheses}

Figure 1 depicts the conceptual model of this research. The model illustrates interwoven relationship of SC integration, value addition and organizational performance. Nowadays, adopting SC integration to assimilate firm operations with vendors and customers is emerged as a strategic source to achieve superior SC performance (Acar and Atadeniz 2015). Beheshti et al. (2014) found the internal and external integrations lead companies toward improved financial performance. Kannan and Tan (2010) argued the most competitive and successful firms are those that are capable of integrating their chain partners and customers into a single network. The strong relationship between suppliers and focal firm fosters the mutual information sharing related to processes, capabilities, products and schedules, assisting formulating production strategies, manufacturing and delivering products on demanded time (Shashi et al. 2018). Besides, Wiengarten et al. (2016) quote a study of Dyer and Singh (1998) which claimed the SC integration is expected to gain high market share, cost reduction and supernormal profit through relationspecific assets, knowledge-sharing routines, complementary resources/capabilities and effective governance. The study of Morita et al. (2018) shows that SC integration can contribute substantially on operational performance of companies, which is further supported by Liu et al. (2013) which illustrates that market orientation is somewhat correlated with SC integration and organizational performance. Recently, Ataseven and Nair (2017) identified integration as a driver of performance and showed that firms with higher level of collaborative practices perform better than those with lower level of collaborative practices. The above arguments lead to the following hypotheses:
H1 External integration has a positive impact on firm performance.

H2 Internal integration has a positive impact on firm performance.

The SC integration has impact not only on organizational performance, but also on the SC value addition of firms. Morash and Clinton (1998) specify the aim of SC integration as adding value by reducing overall costs. Thus, a market-oriented company which wishes to enlarge customer value must strive to lessen buyers' costs. Collective efforts of SC intermediates may help in maximizing the level of SC value addition through reduction in cost, lead time and improvement in quality, availability, reliability and flexibility (Ageron et al. 2012). It will improve customer service, responsiveness, customer's satisfaction and reduce inventory handling cost (Madhan 2012). For example, trustworthy integration with suppliers can assist in prompt and reliable delivery of raw materials and equipment which helps manufacturers to introduce finished products in the market quickly. Zhu et al. (2018) argued effective management of inter-organizational learning could result in more customer value. Moreover, the integration allows for sharing the resources among partners and minimizing the risk of SC failure caused by lack of resources (Shashi et al. 2018). At the same time, strong SC relationship provides opportunities for improving the accuracy of demand information and required inventory as well as significantly reducing the time associated with product design and production planning (Flynn et al. 2010). Moreover, an integrated SC structure can lessen non-value-added activities and also their connected structures (Gunasekaran and Ngai 2004). The better internal and external cooperation leads to quick responses to customer demands and problem-solving which promotes responsiveness (Danese et al. 2013). Bustinza et al. (2017) highlighted the importance of concentric strategic partnerships in successful product and service innovation and thereby creating business value. Accordingly, the present study further proposes the following hypotheses:

H3 External integration has a positive impact on SC value addition.

H4 Internal integration has a positive impact on SC value addition.

High SC value addition makes a distinction between a firm and their competitors by improving customer satisfaction, loyalty, market share and overall organizational performance (Papazoglou et al. 2000). Companies, who offer higher value, retain their partners and customers for longer periods of time which assists in building brand value in each 
segment by improving market share, profitability and sale (Morash and Clinton 1998). The delivery reliabilities are expected to contain the cost of reverse logistics which enables organizations to strengthen their economic performance (Katz, and Boland 2000). Similarly, adjustments to buyer's requirements contribute to extending market share, return on sale, return on investment and stronger seller-buyer relationships (Gunasekaran et al. 2008). Zhang and Wang (2018) showed the effect of service value on a firm's performance.

On the other hand, reducing lead time and increasing the rate of flawless order deliveries can support the focal firm in improving the value of their SC (Shashi et al. 2017). Recently, Shashi et al. (2018) developed a conceptual model and hypnotized value addition positively affects firm performance. Madhan (2012) showed the greater the value creation, the higher the satisfaction and loyalty of customers. Martinez (2014) supported the direct impact of value addition practices on the firm's market performance, customer performance and economic performance. Madhani (2012) stressed linking the values of customers with an effective flow of products can generate a unique competitive edge. Literature has also advocated a high level of value creation is necessary to improve customer satisfaction and corporate image, which further assists in customer retention and increased market share (Pal 2017). For that reason, we assume that $\mathrm{SC}$ value addition helps in balancing and improving the efficiency of organizational performance. Hence, we have another hypothesis:

H5 SC value addition has a positive impact on firm performance.

\section{Measurement}

To test the conceptual model, a seven-point Likert scale from 1 (strongly disagree) to 7 (strongly agree), for the measurement of internal, external integration and value addition constructs and another seven-point Likert scale from 1 (much worse than competition) to 7 (much better than competition) for measurement of firm performance were administered to several Indian companies (see Appendix 1 for more details). The use of the 7-point scale increases the reliability and validity in comparison with the 5-point Likert scale. The 7-point scale has no impact on the results of the exploratory factor analysis (Barnes et al. 1994). The 7-point Likert scales tend to produce better distributions of data (Churchill and Peter 1984). Finstad (2010) conducted a comparative study between the 5-point and 7-point Likert scales and claimed that the 7-point scale provides more accurate results than the 5-point scale. During reliability tests, our scale was found highly reliable with an internal consistency as the loadings of the items of all constructs were above 0.7 , and the Cronbach's alpha coefficients computed to assess each construct were above 0.8 . Here, for external and internal integration, items listed in the studies of Swink et al. (2007) and Danese et al. (2013) are partially used. Value addition variables are also motivated from the study of Papazoglou et al. (2000). In addition, the scales developed by Vickery et al. (2003) and Chen et al. (2004) have been considered for firm performance.

Prior to final data collection, the instrument was pretested in two stages to ensure content validity. Firstly, seven SC experienced researchers were requested to critique the survey instrument for ambiguity, clarity, relevance and to access the level to which the constructs items sufficiently addressed the study subject area. On the basis of researchers' valuable feedbacks, the questionnaire was modified to improve validity. Thereafter, a modified instrument was send to 54 business executives and requested to review its readability, completeness and ambiguity. The feedbacks of these executives assisted in enhancing the instrument efficiency.

Afterward, a large-scale survey was administered by using a multi-survey methodology: postal survey, email survey and field visits to reduce the probability of bias of adopting a single-survey data collection method and to enhance the value of the data by applying a multi-survey methodology (Dillman 2000). In this phase, a total of 610 questionnaires were distributed to several Indian largescale manufacturing companies in different regions, and after 10 days, follow-up telephone calls were made to those company personnel who had not yet participated in the email survey. A total of 408 questionnaires were returned which showed a $66.88 \%$ of survey response rate, but 42 returned questionnaires were unusable due to missing and incomplete feedbacks. Finally, 366 valid responses, yielding a $60 \%$ survey response rate, were digitalized into an SPSS spreadsheet. Based upon the survey results, a summary of the profile of the companies and personnel are presented in Table 1.

Textiles and apparel companies accounted for $15.02 \%$ of the survey respondents which was followed by food and beverages, cement, steel and paper with $11.47,9.83,9.83$ and $9.28 \%$ of response rate, respectively (Table 1). Meanwhile, the highest, i.e., $20.21 \%$, of survey respondents worked as SC managers and purchase, quality control, marketing and training and development accounted for 16.12, 12.56, 9.28 and $8.46 \%$ of survey respondents, respectively (Table 1 ). From the findings, it can be seen that nearly $38 \%$ of the respondents had 6-10 years of working experiences, whereas approximately $26 \%$ of the respondents had 11-15 years of working experience. This study used descriptive statistics, factor analysis and structure equation modeling techniques to analyze the collected data. 
Table 1 Summary of company type and respondents' profile

\begin{tabular}{|c|c|c|c|c|c|}
\hline Industry sector & Frequency & Percentage & Respondents' profile & Frequency & Percentage \\
\hline Textiles and apparel & 55 & 15.02 & Chief executive officer & 9 & 2.45 \\
\hline Pharmaceutical & 26 & 7.10 & General managers & 14 & 3.82 \\
\hline Food and beverages & 42 & 11.47 & Purchase managers & 59 & 16.12 \\
\hline Household goods and personal goods & 31 & 8.46 & Production managers & 31 & 8.46 \\
\hline Cement & 36 & 9.83 & Quality control managers & 46 & 12.56 \\
\hline Power & 14 & 3.82 & Supply chain managers & 74 & 20.21 \\
\hline Paper & 34 & 9.28 & Finance managers & 25 & 6.83 \\
\hline Steel & 36 & 9.83 & Relationship managers & 20 & 5.46 \\
\hline Automobile & 27 & 7.37 & Marketing managers & 34 & 9.28 \\
\hline Electronic & 19 & 5.19 & Training and development & 31 & 8.46 \\
\hline Hardware and equipment & 30 & 8.19 & Other profile & 23 & 6.28 \\
\hline Others & 16 & 4.37 & & & \\
\hline Total & 366 & 100.00 & Total & 366 & 100.00 \\
\hline
\end{tabular}

\section{Non-response bias}

To investigate non-response bias, the recommendations of Armstrong and Overton (1977) of comparing early and later respondents were taken into consideration. In this study, we classified respondents into two groups: early respondents and late respondents into 40 equal numbers. Then, an independent-sample $t$ test was conducted. Results did not indicate statistically significant differences between the early and late groups of respondents.

\section{Goodness of measure}

For reliability analysis, the Cronbach's alpha $(\alpha)$ value was taken into consideration which is a highly accepted measure to evaluate the internal consistency of homogeneity among items. The reliability outputs produced $\alpha=0.876$ for external integration, $\alpha=0.861$ for internal integration, $\alpha=0.844$ for SC value addition and $\alpha=0.884$ for firm performance. In social science research, $\alpha$ values greater than 0.7 show high reliability; $\alpha$ between 0.35 and 0.70 refers to medium reliability and $\alpha$ below 0.35 shows low reliability (Hair et al. 2009). Thus, it is important to point out the validity of the survey instrument.

\section{Results}

At this juncture, the survey data are converted into valuable information by applying the appropriate statistic tools. The results are displayed in Tables 2, 3, 4 and 5 and Fig. 2. An exploratory factor analysis (using principal component factor analysis with varimax rotation method) is done to validate the unidimensionality and appropriateness of measurement scale. The findings indicate that all the instrument items are loaded on the specific construct that they are expected to measure. Moreover, all the item loadings of constructs are greater than 0.50 , which is proposed as the threshold of Hair et al. (2009). The detailed information about integration, value addition and firm performance is explained in the following.

\section{Factor analysis for integration}

The KMO (Kaiser-Meyer-Olkin) ${ }^{1}$ test has revealed a 0.914 (sufficient) inter-correlation and indicated a significant Chisquare $=2003.010$ and degrees of freedom $(D F)=78$. The factor analysis produced two factors, and after revision it was found that all items were in their relevant construct as in the questionnaire. The mean of external integration is calculated as 6.32 with a standard deviation (SD) of 0.665 , and the mean of internal integration is calculated as 6.14 with a SD of 0.762 . In addition, both factors had significant loadings and eigenvalues as well as factors which together explained $63.07 \%$ of the cumulative variance (Table 2 ).

\section{Factor analysis for value addition}

A factor analysis for the seven items of value addition showed that all the factors were expressed as a single factor. Therefore, component matrix lodgings are used. Descriptive statistics calculated a 6.25 mean value and a 0.716 SD for this construct. The Chi-square and DF are 1125.200 and 21, respectively, with $p<0.001$. This construct explains $59.15 \%$ of the total cumulative variance (Table 3 ).

\footnotetext{
${ }_{1} \mathrm{KMO}$ is a test to measure of how suited your data are for factor analysis.
} 
Table 2 Factor analysis results for integration

\begin{tabular}{|c|c|c|c|c|}
\hline No. & Integration items & SE & $\begin{array}{l}\text { External } \\
\text { integration }\end{array}$ & $\begin{array}{l}\text { Internal } \\
\text { integra- } \\
\text { tion }\end{array}$ \\
\hline EX1 & Our major customer shares Point of Sales information with us & 0.050 & 0.782 & \\
\hline EX2 & We share our production planning and demand forecasted information with keys partners & 0.049 & 0.765 & \\
\hline EX3 & We work as a partner with our customers & 0.043 & 0.726 & \\
\hline EX4 & We plan SC activities, collaboratively & 0.050 & 0.721 & \\
\hline EX5 & The establishment of quick ordering systems with suppliers & 0.044 & 0.712 & \\
\hline EX6 & We believe that cooperating with our suppliers is beneficial & 0.046 & 0.688 & \\
\hline EX7 & We share inventory level information with customers & 0.046 & 0.682 & \\
\hline EX8 & We emphasize openness of communications in collaborating with our partners & 0.045 & 0.660 & \\
\hline IN1 & The functions in our plant cooperate to solve conflicts between them, when they arise & 0.047 & & 0.822 \\
\hline IN2 & Our plant's functions work interactively with each other & 0.053 & & 0.805 \\
\hline IN3 & The marketing and finance areas know a great deal about manufacturing & 0.048 & & 0.787 \\
\hline IN4 & The functions in our plant work well together & 0.049 & & 0.762 \\
\hline \multirow[t]{6}{*}{ IN5 } & Our plant's functions coordinate their activities & 0.050 & & 0.752 \\
\hline & Mean & & 6.32 & 6.14 \\
\hline & SD & & 0.665 & 0.762 \\
\hline & Eigenvalue & & 5.324 & 2.26 \\
\hline & Cronbach's alpha & & 0.876 & 0.861 \\
\hline & Percentage variance $(63.07 \%)$ & & 40.95 & 22.12 \\
\hline
\end{tabular}

$\mathrm{KMO}=0.914$, Bartlett's test of sphericity $=2003.010, d f=78$, Sig. 0.000

Table 3 Factor analysis for value addition

\begin{tabular}{llll}
\hline No. & Value addition items & SE & Value addition \\
\hline VA1 & Our company offers high quality products to customers & 0.049 & 0.815 \\
VA2 & Our company adjusts order delivery according to demand & 0.047 & 0.789 \\
VA3 & Our company provides regular supplies & 0.048 & 0.788 \\
VA4 & Our company offers low prices & 0.049 & 0.760 \\
VA5 & Our company provides a high level of customer service & 0.052 & 0.756 \\
VA6 & Our company provides high order delivery speed & 0.050 & 0.750 \\
VA7 & Our company promotes high shipping accuracy & 0.046 & 0.722 \\
& Mean & & 0.625 \\
& SD & & 0.716 \\
& Eigenvalue & & 414 \\
& Cronbach's alpha & & 0.844 \\
& Percentage variance $(59.15 \%)$ & & 59.15 \\
\hline
\end{tabular}

$\mathrm{KMO}=0.919$, Bartlett's test of sphericity $=1125.200, d f=21$, Sig. 0.000

\section{Factor analysis for firm performance}

The firm performance was comprised of five items and was expressed as a single factor. The mean and SD are 6.20 and 0.902 , respectively. The obtained loadings of the component matrix are significant as they are above 0.6. Meanwhile, the KMO, eigenvalue and Chi-square value all indicated a significant factor analysis. The construct explained $78.307 \%$ of the total cumulative variance (Table 4 ).

\section{Results of the structural equation modeling}

The five hypotheses are tested at the 95\% level of significance using the structural equation modeling technique by using version 21 of the AMOS software. Figure 2 shows the corresponding structural equation modeling, and Table 5 indicates the results of the hypothesis tests.

A structural assessment of the full measurement model indicates that the measurement model fits the data as we have a Chi-square minimum value (CMIN) 
Table 4 Factor analysis for firm performance

\begin{tabular}{llll}
\hline Item no. & Firm performance items & SE & Firm performance \\
\hline FP1 & Growth in market share & 0.054 & 0.911 \\
FP2 & Growth in profit & 0.049 & 0.898 \\
FP3 & Growth in return on sales & 0.056 & 0.885 \\
FP4 & Growth in return on investment & 0.047 & 0.867 \\
FP5 & Growth in sales & 0.054 & 0.863 \\
& Mean & & 6.20 \\
& SD & & 0.902 \\
& Eigenvalue & & 0.915 \\
& Cronbach's alpha & & 78.307 \\
& Percentage variance (78.307\%) & &
\end{tabular}

$\mathrm{KMO}=0.888$, Bartlett's test of sphericity $=1450.726, d f=10$, Sig. 0.000

divided by DF equal to $1.675, p=0.000, \mathrm{GFI}=0.913$, adjusted goodness-of-fit index $($ AGFI $)=0.895$, normed fit index $(\mathrm{NFI})=0.913$ and confirmatory factor analysis $(\mathrm{CFI})=0.964$. In addition, the root-mean-square error of approximation (RMSEA) value is 0.043 , which is very good as it is below 0.050 . Therefore, all values related to model fits are acceptable and significant according to the recommendations of Hair et al. (2009).

As displayed in Fig. 2, all five proposed hypotheses are accepted (null hypotheses rejected) based on calculated $p$ values less than 0.01 . The tests of hypotheses $H 1, H 2, H 3$ and $H 4$ provide a strong support that external and internal integration improve firm performance and $\mathrm{SC}$ value addition. Hypothesis 1, which stated external integration has a positive impact on firm performance, was strongly supported (total $\beta=0.63$, C.R. $=8.36$, and $p=0.000$ ). Results offered support the acceptance of hypothesis 2 , which reported internal integration has a positive impact on firm performance (total $\beta=0.49$, C.R. $=8.42$, and $p=0.000$ ). Hypothesis 3, which claimed external integration has a positive impact on value addition, was confirmed (total $\beta=0.51$, C.R. $=7.66$, and $p=0.000$ ). Further, hypothesis 4 also confirmed which claimed that internal integration has a positive impact on value addition (total $\beta=0.35$, C.R. $=6.16$, and $p=0.000$ ). Lastly, hypothesis 5 , which stated that $\mathrm{SC}$ value addition has a positive impact on firm performance, was supported (total $\beta=0.22$, C.R. $=3.96$, and $p=0.000$ ).

Direct and indirect effects

The results show the following positive direct relationships (Table 5):

1. From external integration to firm performance (0.52) and value addition $(0.51)$;

2. From internal integration to firm performance (0.42) and value addition (0.35); and

3. From value addition to firm performance $(0.22)$

Meanwhile, the indirect effect of external integration on firm performance was 0.11 , and the indirect effect of internal integration on firm performance was 0.07 (Table 5).

\section{Managerial implications and discussion}

Academics and practitioners have increasingly paid attention to the impact of integration on firm's performance. However, the literature lacks a study which conceptualizes the integration, $\mathrm{SC}$ value addition, and firm performance in a single model. Thus, the present study extends and complements the prior studies through conceptualizing and empirically testing an integrated model by considering the value addition as a mediating construct. Moreover, the outcomes of this investigation allow managers evaluate the differences between the indirect and direct effects of SC integration that can be taken into consideration to follow performance improvement. The results supported the argument that the performance of Indian manufacturing firms has improved when firms consider both SC integration and value addition practices.

The empirical results demonstrate that both external and internal integrations assist in improving SC value addition by reducing cost and improving flexibility, speed, quality, accuracy, and regular supplies. In the same vein, they directly and indirectly maximize the sales, profit, market share, return on investment and return on sales. This means that a higher level of SC integration contributes to

Table 5 Results for proposed structure equation model

\begin{tabular}{|c|c|c|c|c|c|c|}
\hline No. & Hypothesis & Total effects & Direct effects & C.R. & Indirect effects & Remarks \\
\hline$H 1$ & External integration $\rightarrow$ firm performance & 0.63 & 0.52 & 8.36 & 0.11 & Supported \\
\hline$H 2$ & Internal integration $\rightarrow$ firm performance & 0.49 & 0.42 & 8.42 & 0.07 & Supported \\
\hline$H 3$ & External integration $\rightarrow$ value addition & 0.51 & 0.51 & 7.66 & & Supported \\
\hline$H 4$ & Internal integration $\rightarrow$ value addition & 0.35 & 0.35 & 6.16 & & Supported \\
\hline H5 & Value addition $\rightarrow$ firm performance & 0.22 & 0.22 & 3.96 & & Supported \\
\hline
\end{tabular}


Fig. 2 Structure equation model

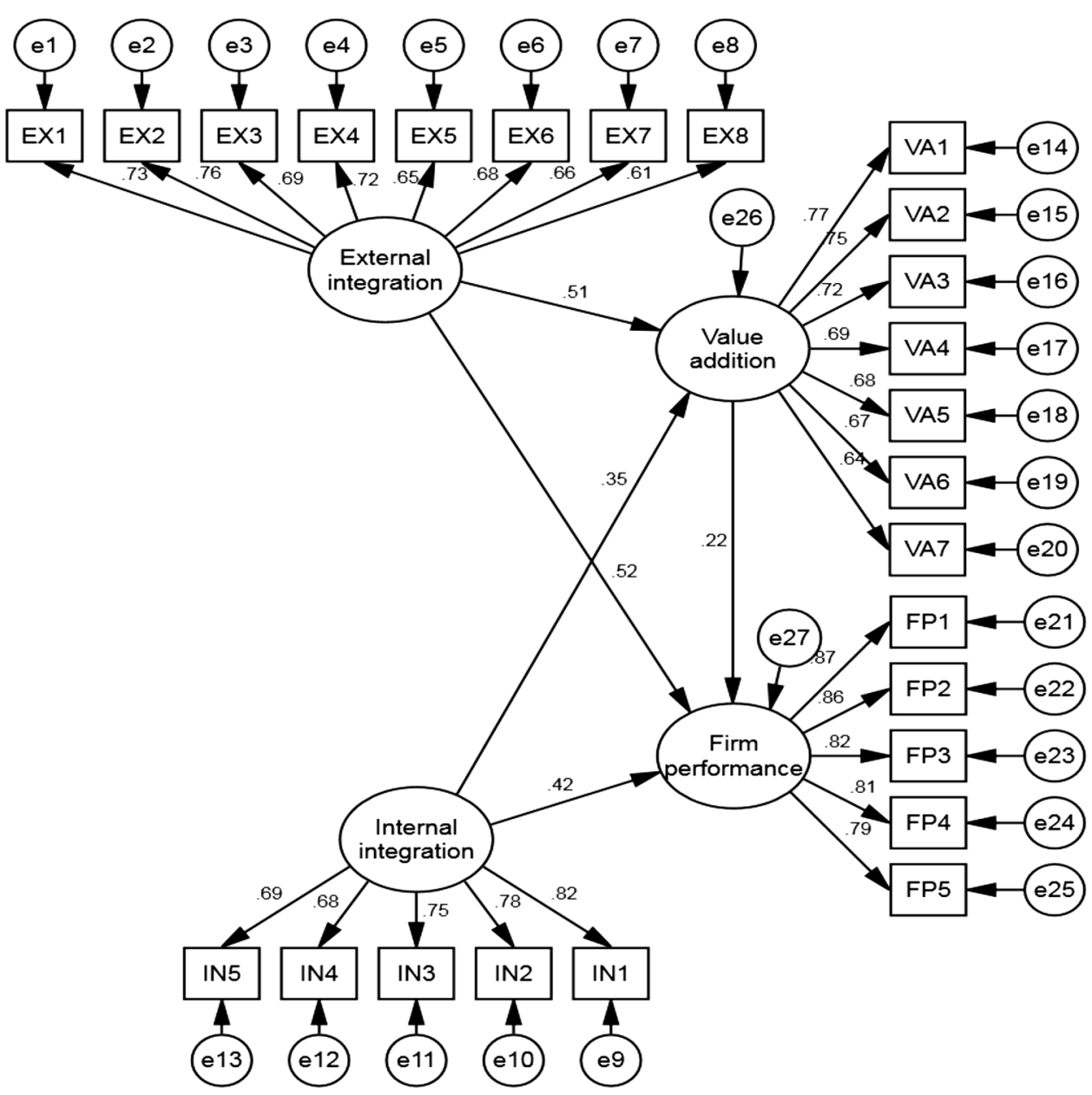

superior firm performance. The findings also show that value addition directly improves firm performance.

The results support the argument of Vickery et al. (2003) that external integration is more powerful than internal integration. Nevertheless, firms cannot deny the role of internal integration in overall success. Second, this study supports the literature in which external and internal integration plays a crucial adding value role (Papazoglou et al. 2000). The result of this paper is also in favor of the fact that SC integration adds values to operations of SC players by increasing delivery accuracy, quality, flexibility, speed, regular supplies and reducing cost. This in turn supports the argument of Narasimhan and Kim (2002) that integrated SC is the strategic leverage of the agreement between the strength of an organization and the operational competence of a SC.

These results have other important implications for practitioners in terms of understanding how to utilize both internal and external integrations most effectively to achieve higher $\mathrm{SC}$ value addition and improved firm performance. The managers need to understand the fact that the integration does not have only a direct effect on the firm's performance, but also an indirect effect mediated by $\mathrm{SC}$ value addition.
That is, the external and internal integrations can directly improve SC value addition as well as directly and indirectly improve the firm performance through $\mathrm{SC}$ value addition. Furthermore, value addition can also directly improve the firm performance. Thus, it is possible for firms to attain paramount performance by enhancing value addition by both external and internal collective efforts. For instance, regular supplies by the supplier enable firms to reduce lead time and improve shipping accuracy and thus increase market share by fulfilling the demand for the maximum number of customers.

Likewise, the effective utilization of internal capacities may help companies to enhance their value addition competence. The integration with suppliers would assist companies to minimize cost and fulfill increased demand promptly and more effectively compared to competitors. The level of value addition can distinguish the firm from market competitors. Despite the strong impact of external integration to the SC value addition and performance practices compare to internal integration, the tight external integration is possible only if the firm has tight internal integration. A company should not overlook the impact of information 
sharing, commitment, cooperation and trust as four pillars of integrated SC. SC integration can also be influenced by several contextual factors, namely firm size, position, capacities and field of operation. Therefore, researchers and executives should be very careful about assuming that SC integration is axiomatically beneficial since the impact of integration and modularity is correlated in a complex fashion.

A successful SC integration can help a company instantly in identifying customer preferences. Integration with customers may facilitate market information sharing which can enable a company and its suppliers to capture hidden market opportunities. Besides, internal integration can enable companies to satisfy customer need promptly. As an example, better coordination between material management, manufacturing and distribution departments can lead to a continuous flow of products in the market.

Enterprises should be fully integrated along SCs to minimize the negative effect of problems such as overstocking, which increases handling costs, and under stocking, which coerce customer to switch to competitors. Tight SC integration can provide operational flexibility to react quickly to external events: if a competitor introduces a new product, a firm can leverage its integrated SC from the product designing stage to the launching stage. It could also implement a just-in-time manufacturing system to minimize the overall cost.

Value addition is found as a potential tool to increase the product life throughout its life cycle, enabling a firm to cope with SC problems and maintain excellence. Regular and unique value addition is highly important in the present global marketplace. The upstream partners can assist in creating values for downstream partners by improving their SC reliability, and downstream partners can assist upstream partners by providing exact timely information about the demand and market environment. In addition, integrated SC stimulates the enterprises to satisfy customer by meeting their demand at low cost and delivery time.

\section{Conclusion}

This study considers the interwoven connection between integration, value addition and firm performance in SC by asking questions related to the degree of relationship between external and internal integrations with value addition and organizational performance on the one hand, and between value addition and organizational performance on the other hand. Answering those questions is important as the current literature is conflicting. To answer these questions, five hypotheses are presented accordingly. A reliable measurement scale is used to implement a large-scale survey of different Indian companies from diverse industries. The results support all research hypotheses, meaning that the tight internal integration in the business processes of $\mathrm{SC}$ players along with tight external integration between those players stimulates SC value addition and performance, while SC value addition is in turn a reinforcing factor for performance. Therefore, SC integration can be seen as a strategic weapon to tackle market complexities and to respond quickly to external market events.

Despite significant contribution of this paper to academic research and business practice, it has some limitations that highlight opportunities and directions for further research. Most of the survey respondents are from largescale manufacturers. As a result, the study results might not be a good represent or of SC integration impact on value addition process and firm performance where the focal companies are small- and medium-sized economic entities. Moreover, by concentrating on many regions and industries the study developed a comprehensive picture of answers to the research questions. However, these associations may not be fully similar for all regions and industries. Likewise, this research is drawn upon the manufacturing sector of India. Therefore, testing the same conceptual framework in the service sector would be an interesting topic for further research.

It would also be interesting to draw the impact of leanness and innovative in the proposed conceptual model. The value addition practices within the present study belong to production and operations domain, therefore including other value addition constructs (e.g., corporate social responsibility, value addition practices to improve environmental sustainability, and retail value addition) would be ruminative. Lastly, this study explored the impact of integration and value addition practices on overall firm's performance. Hence, it would be interesting to examine to what extent integration and value addition practices impact different areas of firm's performance (e.g., innovative performance, production performance, market performance, financial performance and environmental performance).

Acknowledgements The authors would like to thank the anonymous reviewers and the editor for their insightful comments and suggestions. Dr. Madjid Tavana is grateful for the partial support he received from the Czech Science Foundation (GA`CR 19-13946S) for this research.

Open Access This article is distributed under the terms of the Creative Commons Attribution 4.0 International License (http://creativeco mmons.org/licenses/by/4.0/), which permits unrestricted use, distribution, and reproduction in any medium, provided you give appropriate credit to the original author(s) and the source, provide a link to the Creative Commons license, and indicate if changes were made. 


\section{Appendix 1}

This appendix provides a final version of the questionnaire designed for this paper and disseminated in various Indian companies from different industries.

\section{External integration}

Please indicate to what extent you agree/disagree with the following:

\begin{tabular}{ll}
\hline Question & $\begin{array}{l}1=\text { strongly disagree } \\
\text { to } 7=\text { strongly agree }\end{array}$ \\
\hline
\end{tabular}

1. We plan SC activities, collaboratively

2. The establishment of quick ordering systems with suppliers

3. Our major customer shares Point of Sales information with us

4. We work as a partner with our customers

5 . We believe that cooperating with our suppliers is beneficial

6. We emphasize openness of communications in collaborating with our partners

7. We share our production planning and demand forecasted information with keys partners

8. We share inventory level information with customers

\section{Internal integration}

Please indicate to what extent you agree/disagree with the following:

\begin{tabular}{ll}
\hline Question & $\begin{array}{l}1=\text { strongly disagree } \\
\text { to } 7=\text { strongly agree }\end{array}$
\end{tabular}

1. The functions in our plant work well together

2. The functions in our plant cooperate to solve conflicts between them, when they arise

3. The marketing and finance areas know a great deal about manufacturing

4. Our plant's functions coordinate their activities

5. Our plant's functions work interactively with each other

\section{Value addition}

Please indicate to what extent you agree/disagree with the following:
Question

$1=$ strongly disagree to $7=$ strongly agree

1. Our company provides high order delivery speed

2. Our company provides regular supplies

3. Our company adjusts order delivery according to demand

4. Our company provides a high level of customer service

5. Our company offers high quality products to customers

6. Our company promotes high shipping accuracy

7. Our company offers low prices

\section{Firm performance}

Please rate your firm's performance in each of the following areas as compared to the performance of your competitors:

\begin{tabular}{ll}
\hline Question & $\begin{array}{l}1=\text { much worse than competition } \\
\text { to } 7=\text { much better than competi- } \\
\text { tion }\end{array}$
\end{tabular}

1. Growth in sales

2. Growth in profit

3. Growth in market share

4. Growth in return on investment

5. Growth in return on sales

\section{References}

Acar Y, Atadeniz SN (2015) Comparison of integrated and local planning approaches for the supply network of a globally-dispersed enterprise. Int J Prod Econ 167:204-219

Ageron B, Gunasekaran A, Spalanzani A (2012) Sustainable supply management: an empirical study. Int J Prod Econ 140:168-182

Aharonovitz MCS, Vieira JGV, Suyama SS (2018) How logistics performance is affected by supply chain relationships. The International Journal of Logistics Management 29(1):284-307

Armstrong JS, Overton TS (1977) Estimating nonresponse bias in mail surveys. J Mark Res 14(3):396-402

Ataseven C, Nair A (2017) Assessment of supply chain integration and performance relationships: a meta-analytic investigation of the literature. Int J Prod Econ 185:252-265

Barnes JH, Daswar AK, Gilbert FW (1994) Number of factors obtained by chance: a situation study. In: Wilson KJ, Black W (eds) Developments in marketing science, vol 17. Academy of Marketing Science, Nashville

Barrat M (2004) Understanding the meaning of collaboration in the supply chain. Supply Chain Management: An International Journal 9(1):30-42 
Beheshti HM, Oghazi P, Mostaghel R, Hultman M (2014) Supply chain integration and firm performance: an empirical study of Swedish manufacturing firms. Compet Rev 24(1):20-31

Bustinza OF, Gomes E, Vendrell-Herrero F, Baines T (2017) Product-service innovation and performance: the role of collaborative partnerships and R\&D intensity. R\&D Management 49(1):33-45

Chen IJ, Paulraj A (2004) Towards a theory of supply chain management: the constructs and measurements. J Oper Manag 22(2):119-150

Chen IJ, Paulraj A, Lado AA (2004) Strategic purchasing, supply management and firm performance. J Oper Manag 22(5):505-523

Churchill GA, Peter JP (1984) Research design effect on the reliability of rating. J Mark Res 16:360-375

Cooper MC, Lambert DM, Pagh JD (1997) Supply chain management: more than a name for logistics. Int J Logist Manag $8(1): 1-14$

Danese P, Romano P, Formentini M (2013) The impact of supply chain integration on responsiveness: the moderating effect of using an international supplier network. Transp Res Part E 49:125-140

Dillman DA (2000) Mail and internet surveys: the tailored design method, vol 2. Wiley, New York

Droge C, Vickery S, Jacobs M (2012) An empirical study does supply chain integration mediate the relationship between product/process strategy and service performance? Int J Prod Econ 137(2):250-262

Dyer JH, Singh H (1998) The relational view: cooperative strategy and sources of inter-organizational competitive advantage. Acad Manag Rev 23(4):660-679

Finger AB, Flynn BB, Paiva EL (2014) Anticipation of new technologies: supply chain antecedents and competitive performance. Int J Oper Prod Manag 34(6):807-828

Finstad K (2010) Response interpolation and scale sensitivity: evidence against 5-point scales. J Usability Stud 5(3):104-110

Flynn BB, Huo B, Zhao X (2010) The impact of supply chain integration on performance contingency and configuration approach. J Prod Econ 28(1):58-71

Frohlich MT, Westbrook's R (2001) Arcs of integration: an international study of supply chain strategies. J Oper Prod Manag 19:185-200

Green KW, McGaughey R, Casey KM (2006) Does supply chain management strategy mediate the association between market orientation and organizational performance? Supply Chain Manag Int J 11(5):407-414

Gunasekaran A, Ngai EWT (2004) Virtual supply-chain management. Prod Plan Control 15(6):584-595

Gunasekaran A, Lai K, Cheng TCE (2008) Responsive supply chain: a competitive strategy in a networked economy. Omega 36:549-564

Hafezalkotob A, Zamani S (2019) A multi-product green supply chain under government supervision with price and demand uncertainty. J Ind Eng Int 15:193-206

Hair JF, Black WC, Babin BJ, Anderson RE, Tatham RL (2009) Multivariate data analysis. Pearson Education, Inc., Delhi

Hong J-D, Jeong K-Y (2019) Combining data envelopment analysis and multi-objective model for the efficient facility location-allocation decision. J Ind Eng Int 15:315-331

IBEF (2019) Manufacturing sector in India. https://www.ibef.org/indus try/manufacturing-sector-india.aspx. Accessed 13 June 2019

Jacobs MA, Yu W, Chavez R (2016) The effect of internal communication and employee satisfaction on supply chain integration. Int $\mathrm{J}$ Prod Econ 171:60-70

Johnston DA, McCutcheon DM, Stuart FI, Kerwood H (2004) Effects of supplier trust on performance of cooperative supplier relationships. J Oper Prod Manag 22:23-38

Kampstra RP, Ashayeri J, Gattorna JL (2006) Realities of supply chain collaboration. Int J Logist Manag 17(3):312-330
Kang M, Yang MA, Park Y, Huo B (2018) Supply chain integration and its impact on sustainability. Ind Manag Data Syst 118(9):1749-1765

Kannan VR, Tan KC (2010) Supply chain integration: cluster analysis of the impact of span of integration. Supply Chain Manag Int J 15(3):207-215

Kanyoma KE, Agbola FW, Oloruntoba R (2018) An evaluation of supply chain integration across multi-tier supply chains of manufacturing-based SMEs in Malawi. Int J Logist Manag 29(3):1001-1024

Katz JP, Boland M (2000) A new value-added strategy for the US beef industry: the case of US Premium Beef Ltd. Supply Chain Manag Int J 52:99-110

Khorasani ST, Almasifard M (2018) The development of a green supply chain dual-objective facility by considering different levels of uncertainty. J Ind Eng Int 14:593-602

Kim SW (2009) An investigation on the direct and indirect effect of supply chain integration on firm performance. Int J Prod Econ 119:328-346

Kim M, Chai S (2016) Assessing the impact of business uncertainty on supply chain integration. Int J Logist Manag 27(2):463-485

Lambert DM, Cooper MC (2000) Issues in supply chain management. Ind Mark Manag 29:65-83

Lambert DM, Cooper MC, Pagh JD (1998) Supply chain management: implementation issues and research opportunities. Int J Logistics Manag 9(2):1-19

Liao S-H, Kuo F-I, Ding L-W (2017) Assessing the influence of supply chain collaboration value innovation, supply chain capability and competitive advantage in Taiwan's networking communication industry. Int J Prod Econ 191:143-153

Liu H, Ke W, Wei KK, Hua Z (2013) Effects of supply chain integration and market orientation on firm performance. Int J Oper Prod Manag 33(3):322-346

Madhan PM (2012) Value creation through integration of supply chain management and marketing strategy. IUP J Bus Strategy 9(1):7-26

Madhani PM (2012) Value creation through integration of supply chain management and marketing strategy. IUP J Bus Strategy 9(1):7-26

Martinez MG (2014) Co-creation of value by open Innovation: unlocking new sources of competitive advantage. Agribusiness 30(2):132-147

Matthews J (2013) Adding value: getting to the heart of the matter. Perform Meas Metr 14(3):162-174

Morash EA, Clinton SR (1998) Supply chain integration: customer value through collaborative closeness versus operational excellence. J Mark Theory Pract 6(4):104-120

Morita M, Machuca JAD, de los Rios JLP (2018) Integration of product development capability and supply chain capability: the driver for high performance adaptation. Int J Prod Econ 200:68-82

Narasimhan R, Kim SW (2002) Effect of supply chain integration on the relationship between diversification and performance evidence from Japanese and Korean firms. J Oper Manag 20(3):303-323

Noori-daryan M, Taleizadeh AA (2019) Optimizing pricing and ordering strategies in a three-level supply chain under return policy. J Ind Eng Int 15:73-80

Pagell M (2004) Understanding the factors that enable and inhibit the integration of operations, purchasing and logistics. J Oper Prod Manag 22(5):459-487

Pal R (2017) Value creation through reverse logistics in used clothing networks. Int J Logist Manag 28(3):864-906

Papazoglou MP, Ribbers P, Tsalgatidou A (2000) Integrated value chains and their implications from a business and technology standpoint. Decis Support Syst 29:323-342

Pinha DC, Ahluwalia RS (2019) Flexible resource management and its effect on project cost and duration. J Ind Eng Int 15:119-133 
Power D (2005) Supply chain management integration and implementation: a literature review. Supply Chain Manag Int J 10(4):252-263

Qi Y, Huo B, Wang Z, Yeung HYJ (2017) The impact of operations and supply chain strategies on integration and performance. Int $\mathbf{J}$ Prod Econ 185:162-174

Saeed KA, Malhotra MK, Abdinnour S (2018) How supply chain architecture and product architecture impact firm performance: an empirical examination. J Purch Supply Manag 25(1):40-52

Sambasivan M, Siew-Phaik L, Mohamed ZA, Leong YC (2011) Impact of interdependence between supply chain partners on strategic alliance outcomes: role of relational capital as a mediating construct. Manag Decis 49(4):548-569

Sawhney R (2006) Interplay between uncertainty and flexibility across the value chain: towards a transformation model of manufacturing flexibility. J Oper Prod Manag 24(5):476-493

Sebatjane M, Adetunji O (2019) Economic order quantity model for growing items with incremental quantity discounts. J Ind Eng Int. https://doi.org/10.1007/s40092-019-0311-0

Shashi, Singh R, Shabani A (2017) Value-adding practices in food supply chain: evidence from Indian food industry. Agribusiness 33(1):116-130

Shashi, Cerchione R, Singh R, Centobelli P, Shabani A (2018) Food cold chain management: from a structured literature review to a conceptual framework and research agenda. Int J Logist Manag 29(3):792-821

Shashi, Centobelli P, Cerchione R, Singh R (2019) The impact of leanness and innovativeness on environmental and financial performance: insights from Indian SMEs. Int J Prod Econ 212:111-124

Shou Y, Li Y, Park Y, Kang M (2018) Supply chain integration and operational performance: the contingency effects of production systems. J Purch Supply Manag 24(4):352-360

Smith AD, Rupp WT (2013) Supply supplier integration, procurement, and outsourcing: case study of SCM social capital benefits. Int J Logist Syst Manag 14(2):221-241

Sofiana A, Rosyidi CN, Pujiyanto E (2019) Product quality improvement model considering quality investment in rework policies and supply chain profit sharing. J Ind Eng Int. https://doi.org/10.1007/ s40092-019-0309-7

Swink M, Narasimhan R, Wang C (2007) Managing beyond the factory walls: effects of four types of strategic integration on manufacturing plant performance. J Oper Prod Manag 25(1):148-164

Tarifa-Fernandez J, De Burgos-Jimenez J (2017) Supply chain integration and performance relationship: a moderating effects review. Int J Logist Manag 28(4):1243-1271

Vickery SK, Jayaram J, Dröge C, Calantone R (2003) The effects of an integrative supply chain strategy on customer service and financial performance: an analysis of direct versus indirect relationships. J Oper Prod Manag 21(5):523-539

Wang B, Kang Y, Childerhouse P, Huo BM (2018) Interpersonal and inter-organizational relationship drivers of supply chain integration. Ind Manag Data Syst 118(6):1170-1191

Wiengarten F, Humphreys P, Gimenez C, McIvor R (2016) Risk, risk management practices, and the success of supply chain integration. Int J Prod Econ 171:361-370

Zailani S, Rajagopal P (2005) Supply chain integration and performance: US versus East Asian companies. Supply Chain Manag Int J 10(5):379-393

Zhang F, Wang C (2018) Dynamic pricing strategy and coordination in a dual-channel supply chain considering service value. Appl Math Model 54:722-742

Zhao G, Feng T, Wang D (2015) Is more supply chain integration always beneficial to financial performance? Ind Mark Manag 45:162-172

Zhu Q, Krikke H, Caniels MCJ (2017) Integrated supply chain risk management: a systematic review. Int J Logist Manag 28(4):1123-1141

Zhu Q, Krikke H, Caniels M (2018) Supply chain integration: value creation through managing inter-organizational learning. Int $\mathbf{J}$ Oper Prod Manag 38(1):211-229 